\title{
Perancangan Blog Guru untuk Penyediaan Bahan Ajar di Era Pembelajaran Abad 21
}

\author{
Nurmida Catherine Sitompul ${ }^{1}$, Rufi'i $^{2}$, Ibut Priono Leksono ${ }^{3}$, Heri Wahyu Rejeki ${ }^{4}$ \\ 1,2,3Program Studi Teknologi Pendidikan, Pascasarjana, Universitas PGRI Adi Buana Surabaya, \\ ${ }^{4}$ Guru SMP Negeri 3 Krian, Sidoarjo, Jawa Timur \\ *e-mail: nurmida.catherine.s@unipasby.ac.id ${ }^{1}$, rufii@unipasby.ac.id ${ }^{2}$,ibutpriono@gmail.com³ \\ heriwahyu53@gmail.com
}

\begin{abstract}
Now a day world is changing complexity and unpredicted which as characteristic in 21st century. These conditions asked severals solutions which more complex according to context. The purpose of education reformulated its goal that to prepare students to be a problem solver. Teaching with problem base learning needs many kinds of learning resources. All these kinds of information will be used of the students to analyses the problems from many points of views. Blog is one of application can be provided informations/datas. Fortunately, almost all schools ini city have already have computers and internets facilitation, but still do not use yet for learning. The purpose of this activity is to train teachers to desing and create their own Blog to facilitate student's learning. The result showed that all teachers can create a Blog for their Subject. For the future Teacher BLOG should be develop regulary.
\end{abstract}

Keywords: learning materials, Teacher's BLOG, Digital Data, problem base learning

\begin{abstract}
Abstrak
Perubahan yang bersifat takterstruktur dan terus menerus merupakan ciri abad 21 yang menimbulkan banyak permasalahan kompleks. Kondisi ini menuntut cara-cara penyelesaian masalah yang semakin kompleks dan sesuai konteksnya. Menyikapi keadaan ini dunia pendidikan memformulasikan kembali tujuan pembelajaran di Era abad 21 yaitu menyiapkan generasi yang cakap dalam mengindentifikasi masalah dan penyelesaiannya. Pembelajaran yang berbasis pemecahan masalah memerlukan ketersediaan informasi yang sangat variatif dari berbagai konteks, karena pemahaman suatu konsep lebih lengkap bila dipelajari dari berbagai sudut pandang. BLOG merupakan aplikasi yang dapat dimanfaatkan untuk guru menyediakan bahan ajar berbentuk digital dan dapat diperbaharui dari waktu ke waktu. Sekolah di perkotaan pada umumnya memiliki website namun belum dimanfaatkan untuk pembelajaran, jaringan internet yang memadai dan guru IT. Produk Desain Blog para guru setelah mengikuti pelatihan ini cukup baik dan layak dipergunakan untuk pembelajaran. Pengembangan dan pembaharuan baik isi dan desain Blog Guru harus terus dilakukan sesuai dengan konteks pembelajaran.
\end{abstract}

Kata kunci: materi pembelajran, BLOG Guru, data digital, permbelajaran berbasis masalah

\section{PENDAHULUAN}

Abad 21 ditandai dengan sejumlah fenomena yang merubah kehidupan manusia. Perubahan ini sangat dipicu oleh kemajuan pada bidang Information and Communications Technology (ICT) sehingga abad ini dikenal juga dengan Revolusi Industri 4.0. Kemajuan ICT telah sampai pada taraf yang sophistificated dimana tersedianya data atau informasi dalam jumlah yang tidak terbatas dengan berbagai bentuk format dan tersedia dalam waktu yang sangat singkat. Kondisi ini yang memunculkan nama lain dari abad ini yaitu Era Big Data.

Era Big Data adalah era dimana informasi/data tersedia secara masif, sangat cepat, beragam format dan dapat diakses dari mana saja dan kapan saja (dimana ada internet). Dampak yang paling besar dari era perkembangan teknologi ini adalah digitalisasi dan otomatisasi di berbagai sektor kehidupan manusia, juga ke sekolah (Cope \& Kalantzis, 2016). Fenomena ini mengubah cara manusia berinteraksi dan mengelola aktivitas kehidupannya dan pada akhirnya mengubah cari berpikir. Laporan The Future of Jobs Report 2018 dikeluarkan oleh World 
Economic Forum (2018) menguraikan analisis pekerjaan di masa depan yang tidak pernah terpikirkan sebelumnya dan seklaigus menghilangkan banyak pekerjaan yang ada sekarang. Fenomena perubahan yang sasngat cepat ini dengan sejumlah karakteristiknya menunjukkan perubahan cara hidup manusia dan menuntut keterampilan-keterampilan baru untuk sanggup menyelesaian permasalah-permasalah sebagai akibat dari perubahan yang sangat cepat. Kemampuan pemecahan masalah menjadi semakin penting sebagai akibat langsung era yang terus berubah. Inilah yang mendorong sektor pendidikan untuk mengubah tujuan pendidikan di abad 21 ini.

Sudah saatnya bidang pendidikan memformulasikan kembali tujuan-tujuan pembelajaran di sekolah karena sudah tidak dapat dipertahankan lagi karena tidak sesuai dengan kompetensikompetensi untuk hidup di Revolusi Industri 4.0. Lai, Yarbro, DiCerbo, and de Geest (2018) memprosisikan bahawa Pembelajaran Abad 21 ditujukan untuk menumbuhkan 4 keterampilan utama yang dikenal dengan singkatan 4 Cs Skill (Creativity, Collaboration, Critical Thinking dan Communication.) atau kreatifitas, kolaborasi, berpikir kritis dan komunikasi Keempat keterampilan utama ini diharapkan mempersiapkan peserta didik menjadi seorang problem solver. Keterampilan pemecahan masalah menjadi pusat dari pengembangan sumberdaya manusia karena perubahan-perubahan yang begitu cepat menimbulkan masalah-masalah baru yang semakin kompleks.

Kebijkan Kementerian Pendidikan dan Kebudayaan (2014) melalalui Kurikulum 2013 telah mengantisipasi kondisi ini dengan menformasikan metode-metode berbasis masalah yaitu Pembelajaran berbasis masalah (Problem Based Learning), penemuan (Inquiry Learning) dan proyek (Project Based Learning). Metode pembelajaran masalah adalah metode yang meningkatkan keterampilan berpikir (Hanipah, Florentius, dan Rifai: 2018, Núñez-del-Prado and Goméz, 2017).

Pembelajaran berbasis masalah memerlukan informasi atau data yang bersifat rill dan kontekstual dari berbagai sumber yang berbeda. Data dari beragam sudut pandang yang berbeda tersebut kemudian menjadi bahan pembelajaran bagi peserta didik untuk dilatih menemukan masalah dan penyelesaiannya (David, 2014). Kemajuan ICT yang semakin canggih telah memungkinkan tersedianya data sebagai bahan ajar yang sangat kaya bagi peserta didik. Kemajuan ICT telah dimanfaatkan di sekolah-sekolah, khususnya diperkotaan, telah diterlihatnya website sekolah. Digitalisasi secara global telah masuk ke dunia persekolahan (Cope \& Kalantzis, 2016). Pada tingkat nasional misalnya digitalisasi di perpustakaan (Rahmah, E., Emidar \& Zulfikarni, 2018; Maslim \& Adithama, 2019) ataupun administratif (Setianingsih, Rosana dan Setyawarno, 2018). Fasilitas ICT bila dikembangkan dapat dimanfaatkan dalam pembelajaran namun belum banyak dilakukan. Demikian juga sekolah-sekolah di kota Surabaya dan sekitarnya termasuk Sidoarjo. Kondisi ini sangat disayangkan dan menjadi pendorong bagi Program Magister (S2) Teknologi Pendidikan UNIPA Surabaya untuk melakukan pendekatan kepada sekolah agar menggunakan ICT untuk pembelajaran mulai dari tingkat yang paling sederhana yang bisa dilakukan oleh para guru. Pelatihan yang sama telah dilakukan di SMPN 3 Taman dengan produk BLOG Guru yang cukup layak sebagai bahan pembelajaran (Sitompul, Rufi'i, Priono, dan Rejeki, 2019).

Pemilihan tempat pelaksanaan pengabdian adalah di SMP Negeri 3 Krian, Sidoarjo karena memiliki website, fasilitas internet dan laboratorium komputer. Saat ini Website sekolah lebih bersifat administratif untuk memperkenalkan sekolah dengan berbagai fasilitas, kegiatan dan prestasi para peserta didik atau para guru. Sekolah ini juga terdapat Laboratorium Komputer yang memang dipakai untuk penyelenggaraan ujian berbasis komputer misalnya UNBK di lingkungan Kabupaten Sidoarjo.

Mengingat kegiatan ini adalah awal dari inovasi penggunaan ICT di persekolahan maka aplikasi Blog dipilih karena relatif sederhana terlihat cukjup banyak individual yang memiliki Blog sendiri. Selain itu Pusat Ilmu Pengetahuan dan Teknologi atau Puspiptek (2018) salah satu lembaga di bawah naungan Kementerian Riset, Teknologi, Dan Pendidikan Tinggi Republik 
Indonesia pernah mengadakan kompeteni desain BLOG yang hasilnya di pakai untuk mempublikasikan lembaga ini. Selain itu Lembaga setingkat regional Asia Tenggara yaitu secara Online.

SEAMEO SEAMOLEC (https://seamolec.org/) juga menyelengarakan pelatihan Blog

Blog sangat sesuai dimanfaatkan sebagai sumber bahan ajar karena mampu untuk menampilkan data digital dalam berbagai format words, spreadsheet, pdf, ppt, film, animasi dan sebagainya. Masing-masing format tersebut memiliki kemampuan khusus untuk memberikan pengalaman belajar (Degeng, 2017). Desain pemelajaran BLOG merupakan sarana yang dapat dipakai oleh para guru untuk menyediakan sumber belajar sebanyak-banyak, beragam, bermcammacam format dan yang paling penting adalah dapat diperbaharui (up to date) dari waktu ke waktu. Pemahaman konsep-konsep pembelajaran dari berbagai sudut pandang adalah cara untuk seseorang dapat memahami lebih lengkap (Carr, 2018). Sekolah SMP Negeri 3 Krian, Sidoarjo sangat potensial untuk mengembangkan Blog Guru, karena Sekolah model ini memiliki 3 Laboratorium Komputer dengan total jumlah 110 komputer dan jaringan internet/hot spot dapat diakses di seluruh sekolah. Gambar 1 adalah halaman depan website sekolah.

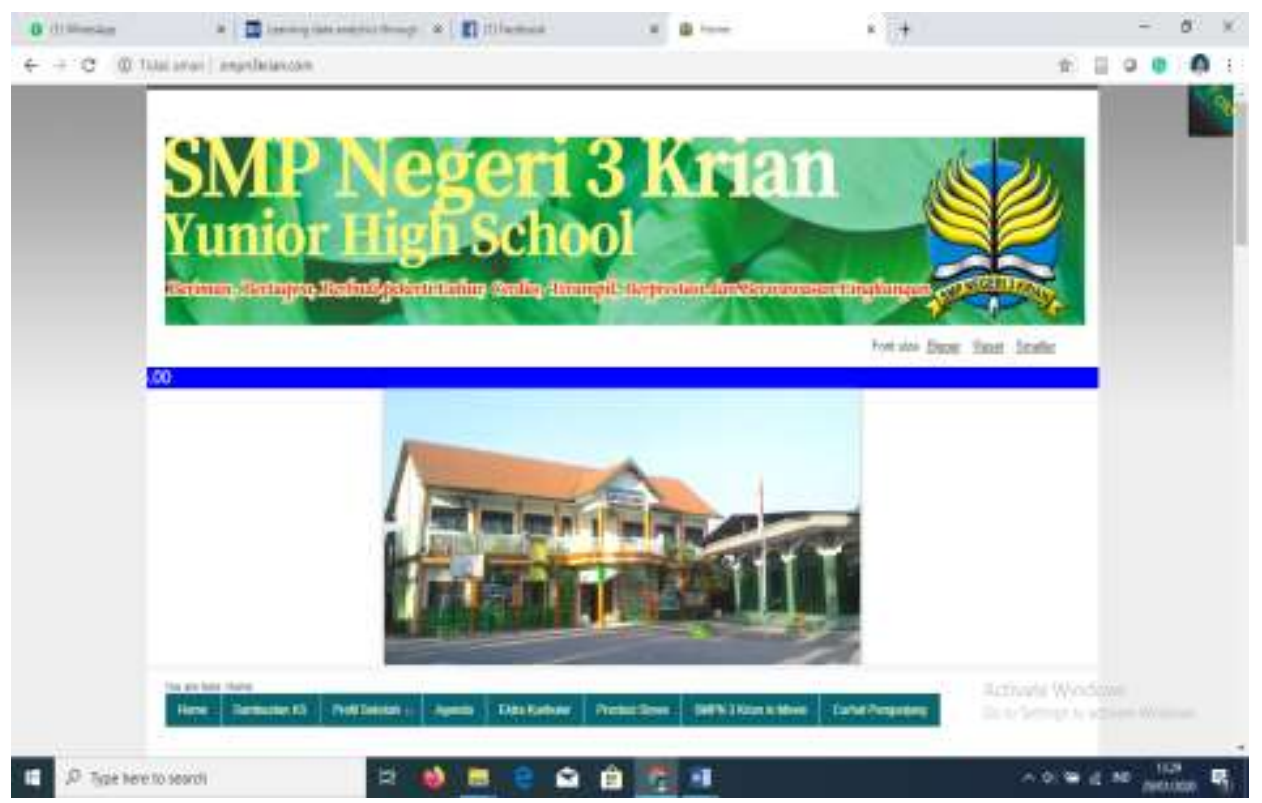

Gambar 1. Website SMPN 3 Krian Sidoarjo (sumber: http://www.smpn3krian.com/)

Kegiatan pengabdian kepada masyarakat ini menghasilkan luaran sebagai berikut: 1) peserta mendapatkan wawasan tentang Pembelajaran Abad 21 dan fenomena perubahan yang terjadi, 2) landasan teoritik dan praktis tentang pembelajaran online secara umum dan pembelajaran Blog secara khusus; 3) peserta dapat mendesain Blog untuk mata pelajarannya sendiri yang diampu, 3) Website SMP Negeri 3 Krian Sidoarjo telah menyediakan menu Blog Guru yang dapat dipakai untuk pembelajaran. Jumlah peserta adalah 45 orang, sedangkan yang diundang adalah 50 orang.

\section{METODE}

Kegiatan pengabdian masyarakat diawali dengan analisis kebutuhan sekitar awal tahun 2019. Informasi diperoleh dari Kepala Sekolah SMP Negeri 3 Krian, Sidoarjo yang sekaligus adalah alumni Program Magister (S2) Teknologi Pendidikan. Setelah melakukan diskusi intensif maka ditemukan kesepakatan untuk melakukan kegiatan dan secara resmi dilakukan dengan mengirimkan Surat undangan ke sekolah pada akhir bulan Maret 2019. 
Kegiatan ini dilakukan dengan 2 metode yaitu 1) pelatihan dan 2) pendampingan. Selain itu juga dilakukan kegiatan 3) Penutupan yang kegiatn utama adalah presentasi BLOG Guru dan penyerahan sertifikat simbolik. Pelaksanaannya sebagai berikut:

1) Pelatihan bertujuan untuk menyediakan landasan teoritik dan konseptual pembelajaran Abad 21 khususnya mengenai online learning praktek mendesain blog untuk setiap guru.

Pelatihan di laksanakan 2 kali. Pelatihan I dilakukan di kampus II UNIPA Surabaya pada tanggal 2 Mei 2019. Pelatihan ke II di lakukan di sekolah pada tanggal 3 Agustus 2019, yang sebenarnya dilakukan pada bulan juni, tapi mengalami perubahan karena berbagai aktivitas di kedua pihak.

Kegiatan ini terdiri dari pemaparan konsep-konsep pembelajaran Abad 21 dan dilanjutkan dengan pelatihan desain BLOG. Materi pada awal pelatihan adalah:

(1) Pembelajaran Abad 21;

(2) Pembelajaran pada Era Revolusi 4.0 dan

(3) Strategi Pembelajaran Era Big Data.

Nara sumber adalah para dosen program studi Teknologi Pendidikan. Diharapkan dengan penyampaian materi ini para guru mendapatkan wawasan global tentang berbagai fenomena makro di dunia dan bagaimana hal tersebut mempengaruhi pendidikan. Gambar 2 adalah para nara sumber dan peserta pelatihan.

Pada bagian metode penerapan, uraikanlah dengan jelas dan padat metode yang digunakan untuk mencapai tujuan yang telah dicanangkan dalam kegiatan pengabdian. Hasil pengabdian itu harus dapat diukur dan penulis diminta menjelaskan alat ukur yang dipakai, baik secara deskriptif maupun kualitatif. Jelaskan cara mengukur tingkat ketercapaian keberhasilan kegiatan pengabdian. Tingkat ketercapaian dapat dilihat dari sisi perubahan sikap, sosial budaya, dan ekonomi masyarakat sasaran.

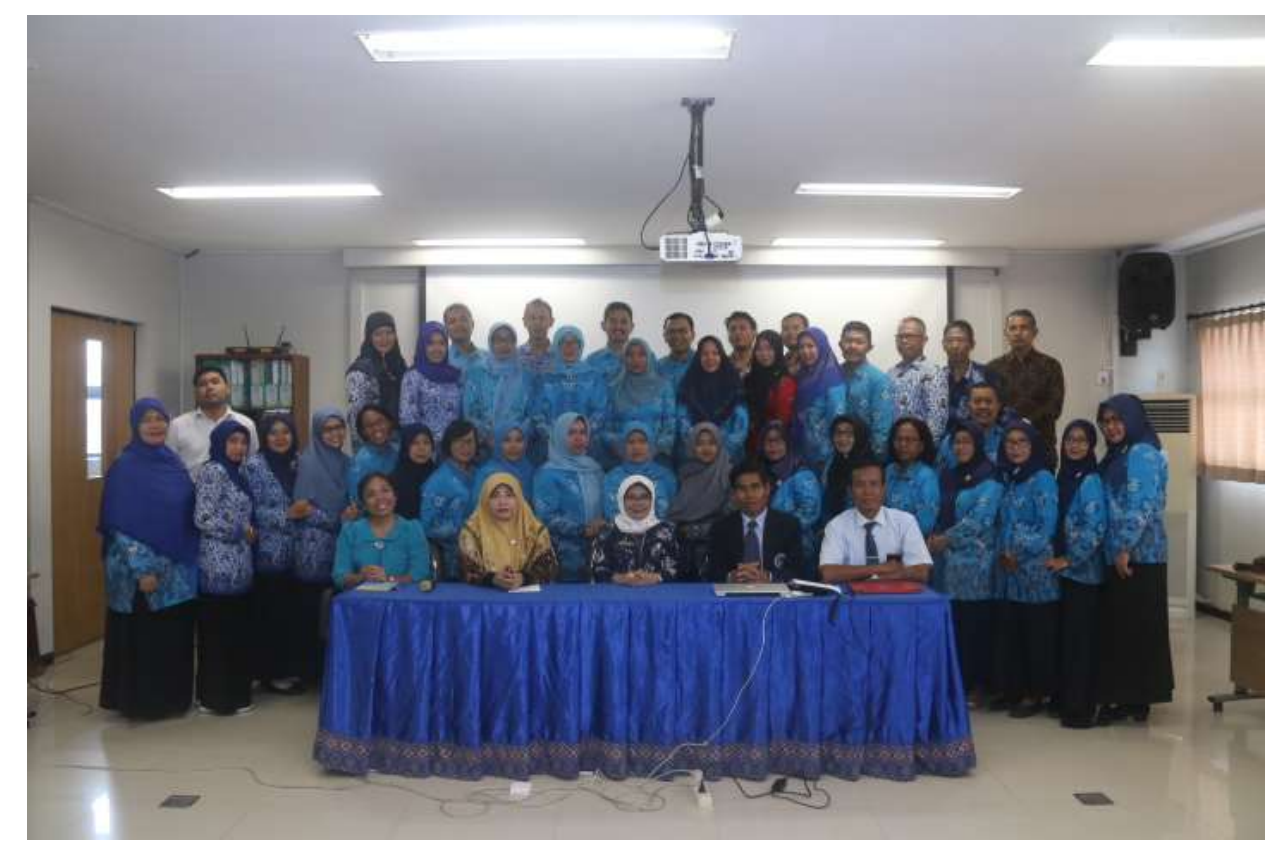

Gambar 2. Nara sumber dan peserta pelatihan

Setelah istirahat siang dilanjutkan kegiatan praktek desain BLOG. Praktek dilakukan mulai dari mempersiapkan hal yang paling mendasar, yaitu memastikan bahawa setiap peserta telah memiliki akun surat elektronik atau email. Sebagian besar guru telah memiliki akun email 
tapi terdapat beberapa peserta yang lupa password dan nama email. Hal ini ini tidak luput dari perhatian fasilitator. Terdapat 1 orang guru yang telah memiliki Blog pribadi.

Desain BLOG dibuat sesuai karakteristik mata pelajaran yang diampu guru, dengan sejumlah menu yang cukup variatif. Setelah selesai pelatihan, para peserta diminta mempersiapkan materi pelajarannya masing-masing dan diminta melanjutkan desain BLOG. Kegiatan berlangsung dari pagi sampai dengan pukul 17.00 WIB.

Gambar 3 menunjukkan suasana pelatihan di ruang perkuliahan program studi. Setelah dilakukan pelatihan mendesain BLOG dan diharapkan kegiatan dilajutkan oleh masing-masing guru setelah pelatihan secara mandiri atau bersama-sama dengan rekan guru di sekolah. Kegiatan pendapingan adalah memberikan fasilitator ke sekolah selama beberapa hari untuk mendampingi guru sehingga para guru mendapatkan solusi ketika menghadapi persoalan. Pendamping dilakukan langsung oleh Kepala Laboratorium Multimedia.

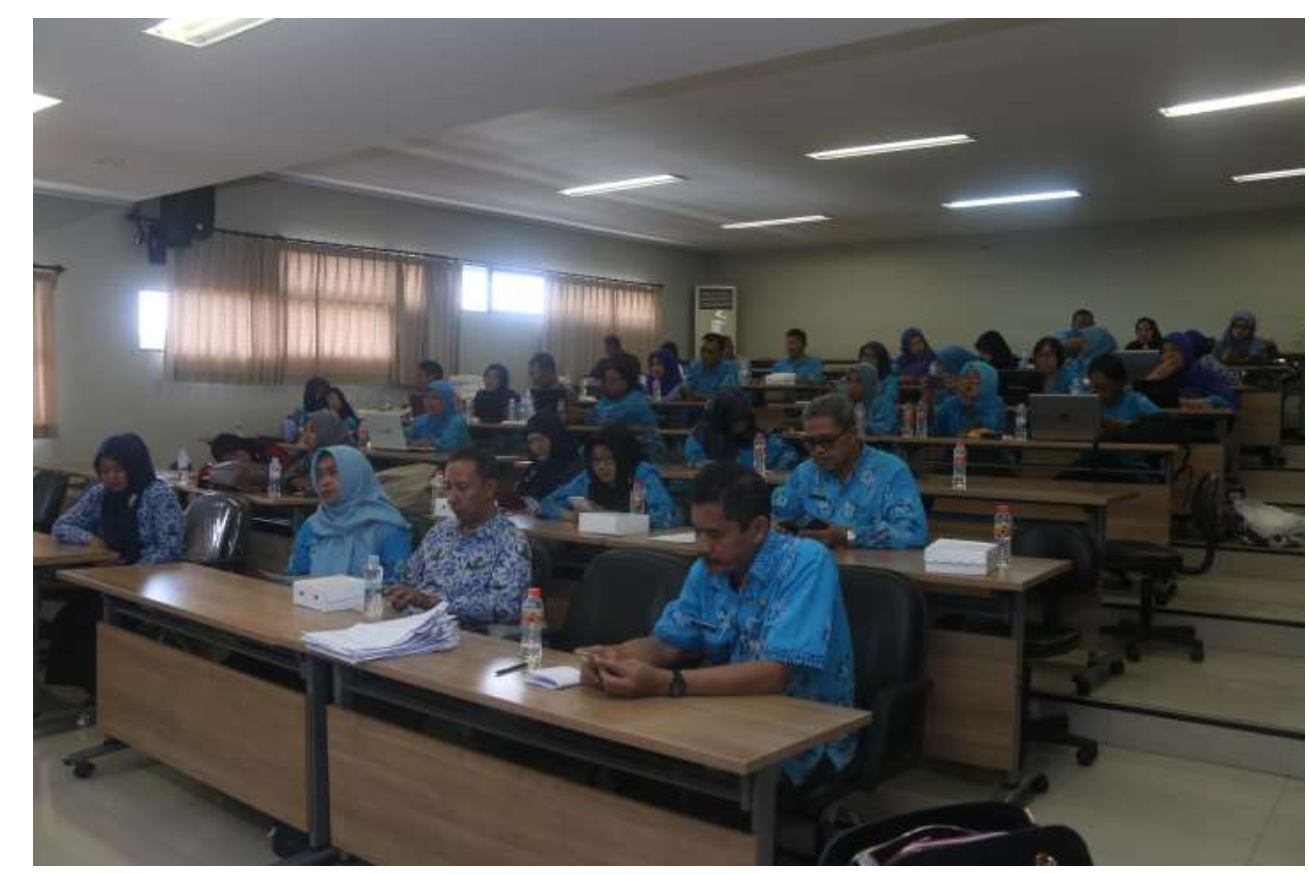

Gambar 3. Para peserta pelatihan mengikuti presentasi dari nara sumber

2) Pendampingan. Aktivitas utama dalam kegiatan ini adalah mendampingi para guru dalam mendesain dan melengkapi BLOG masing-masing.

Pendampingan dilaksanakan pada tanggal 15 dan 28 Mei 2029 di Laboratorium sekolah sehingga sangat memudahkan para guru untuk tetap mengikuti kegiatan pendampingan dan sekaligus tetap melaksanakan tugas di sekolah yang tidak bisa ditinggalkan. Gambar 4 menunjukkan suasana pendampingan Laboratorium Komputer. 


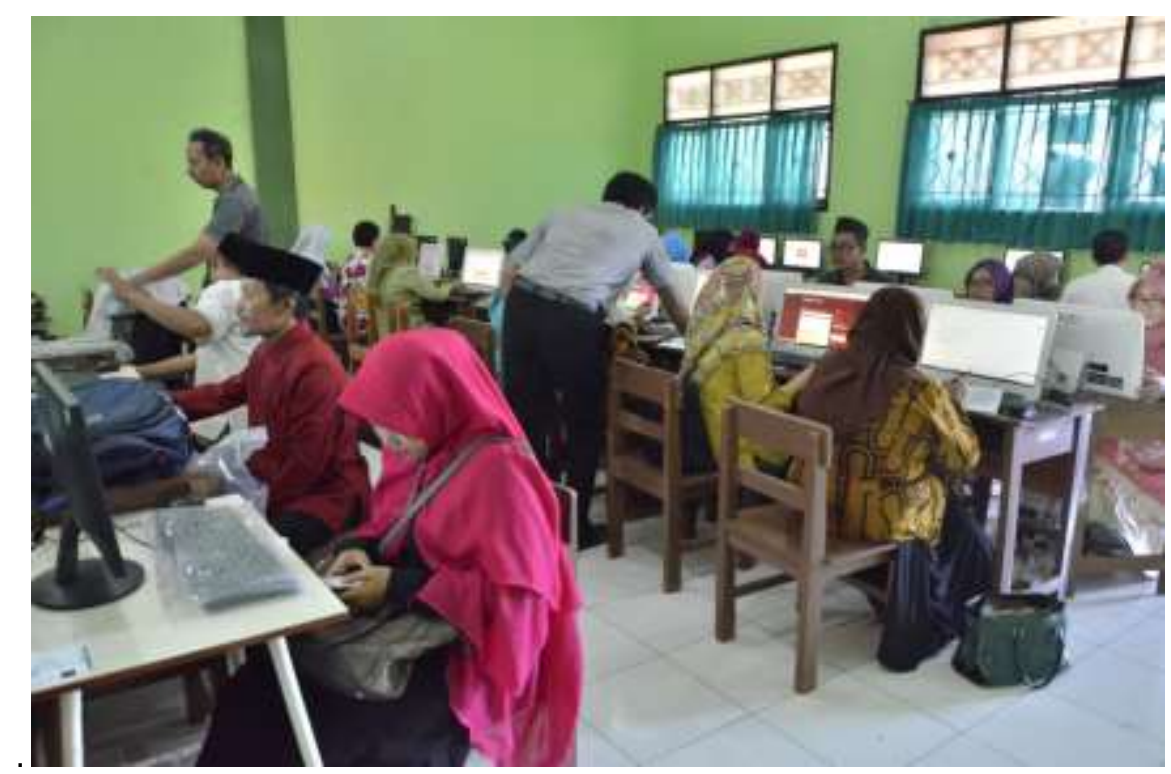

Gambar 4. Suasana kegiatan pendampingan di Ruang Komputer SMPN 3 Krian, Sidoarjo

3) Penutup. Kegiatan penutup diisi dengan presentasi Blog Guru (Gambar 5).

Blog guru lengkap dapat diakses di Lama website sekolah dengan judul Ruang Belajar. Selain itu diserahkan juga sertifikat simbolik dan kemudian penutupan acara.

Gambar 7 adalah foto bersama untuk endokumentasikan kegiatan ini.

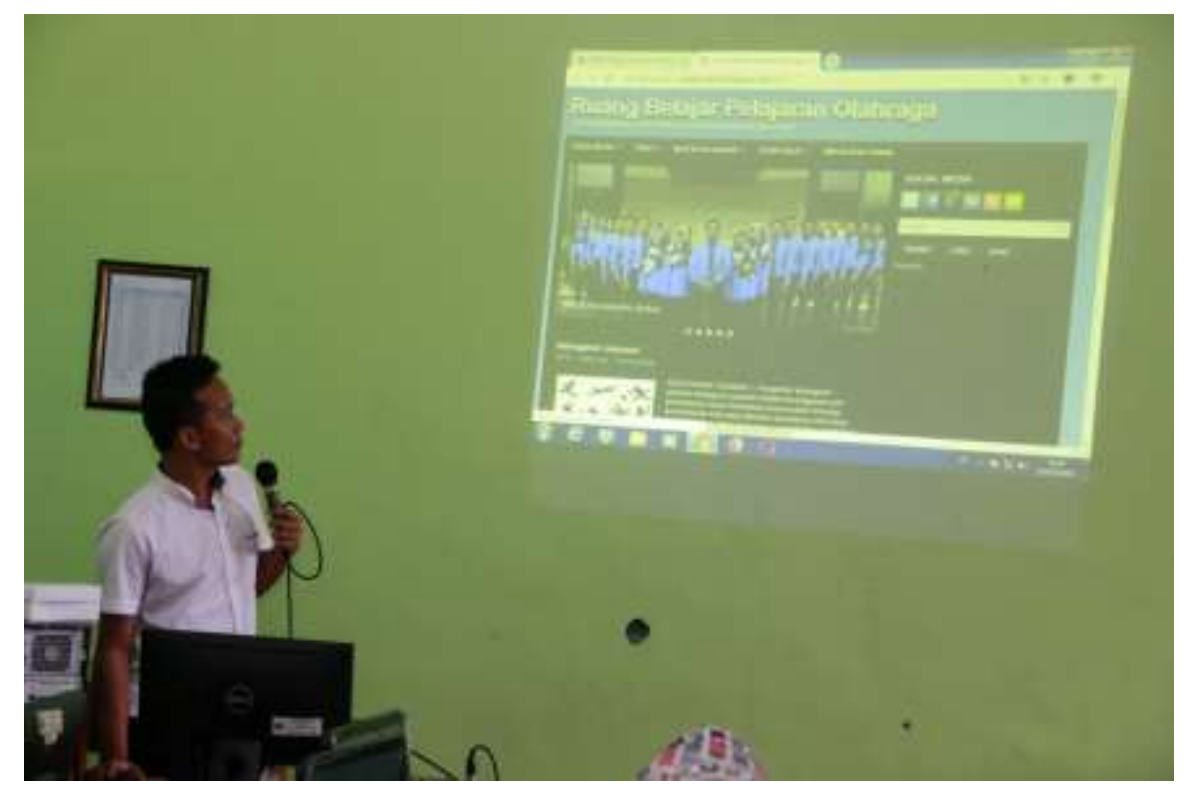

Gambar 5. Salah seorang guru mempresentasikan desain BLOG-nya

\section{HASIL DAN PEMBAHASAN}

Blog Guru sebanyak 41 sudah dapat di lihat pada website sekolah dengan judul Ruang Belajar (Gambar 6). 


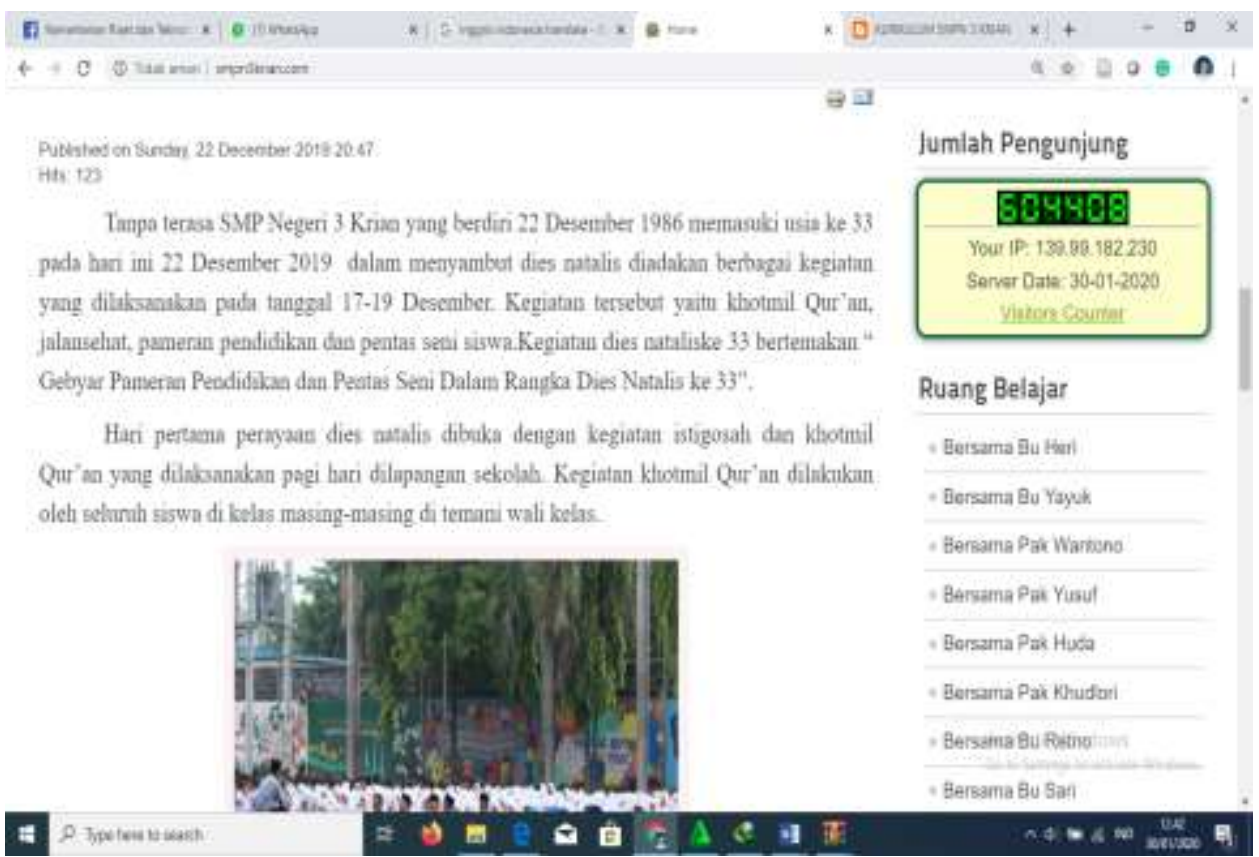

Gambar 6. Daftar alamat BLOG guru (sumber: (http://www.smpn3krian.com/).

Dua karya BLOG Guru di tampilkan pada Gambar 7 dan 8. Pada Gambar 7 menampilkan BLOG atas nama Bapak Wantono yang mengasuh mata pelajaran matematika. Blog di desain atas 6 menu utama. Ada menu materi-materi dan soal dan juga diisi dengan musik.

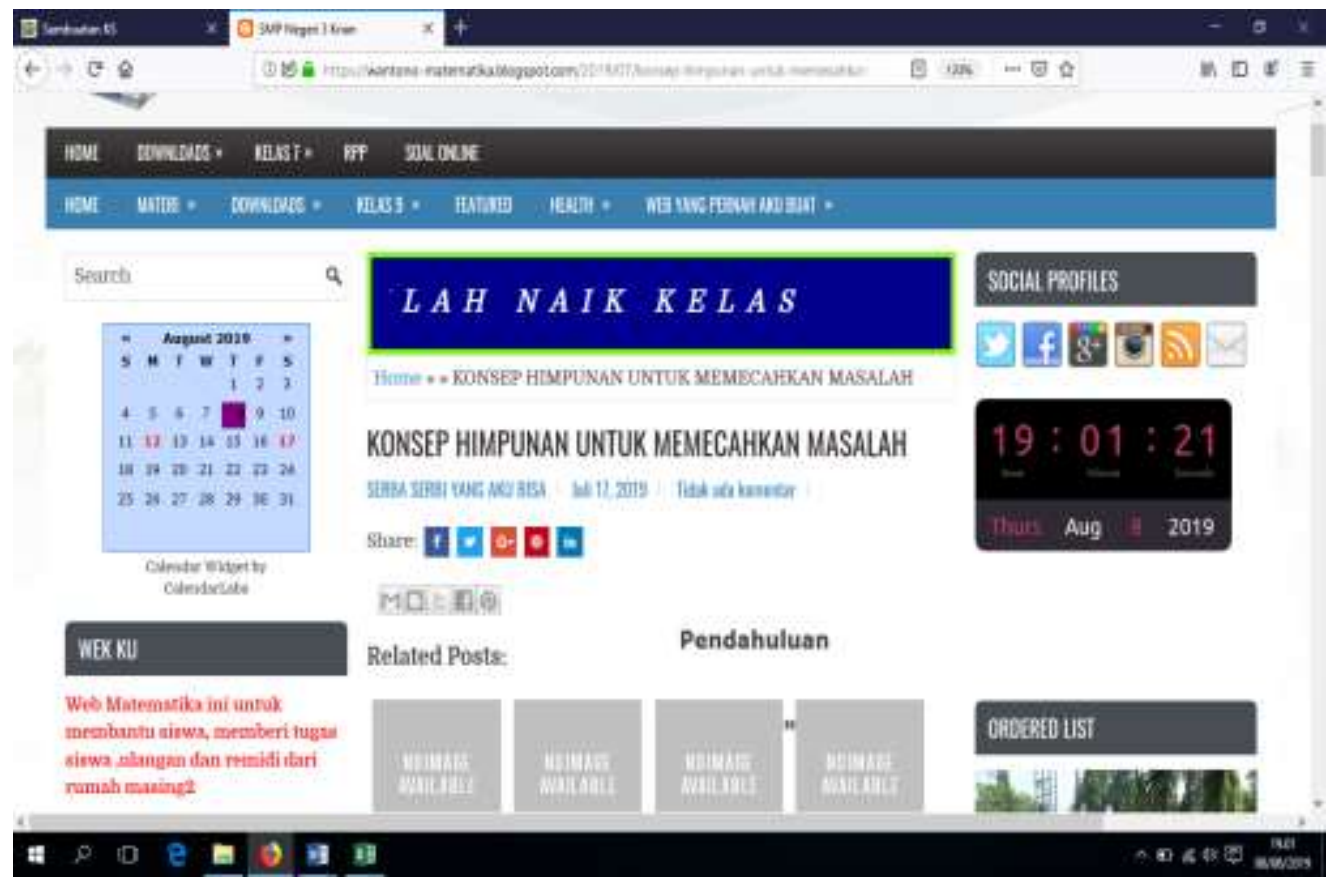

Gambar 7. Blog Pak Wantono dengan alamat Blog https://wantono-matematika.blogspot.com/ 
Gambar 8 menampilkan Blog atas nama Pak Jusuf yang mengasuh mata pelajaran TIK atau Teknologi Informatikda dan Komunikasi.

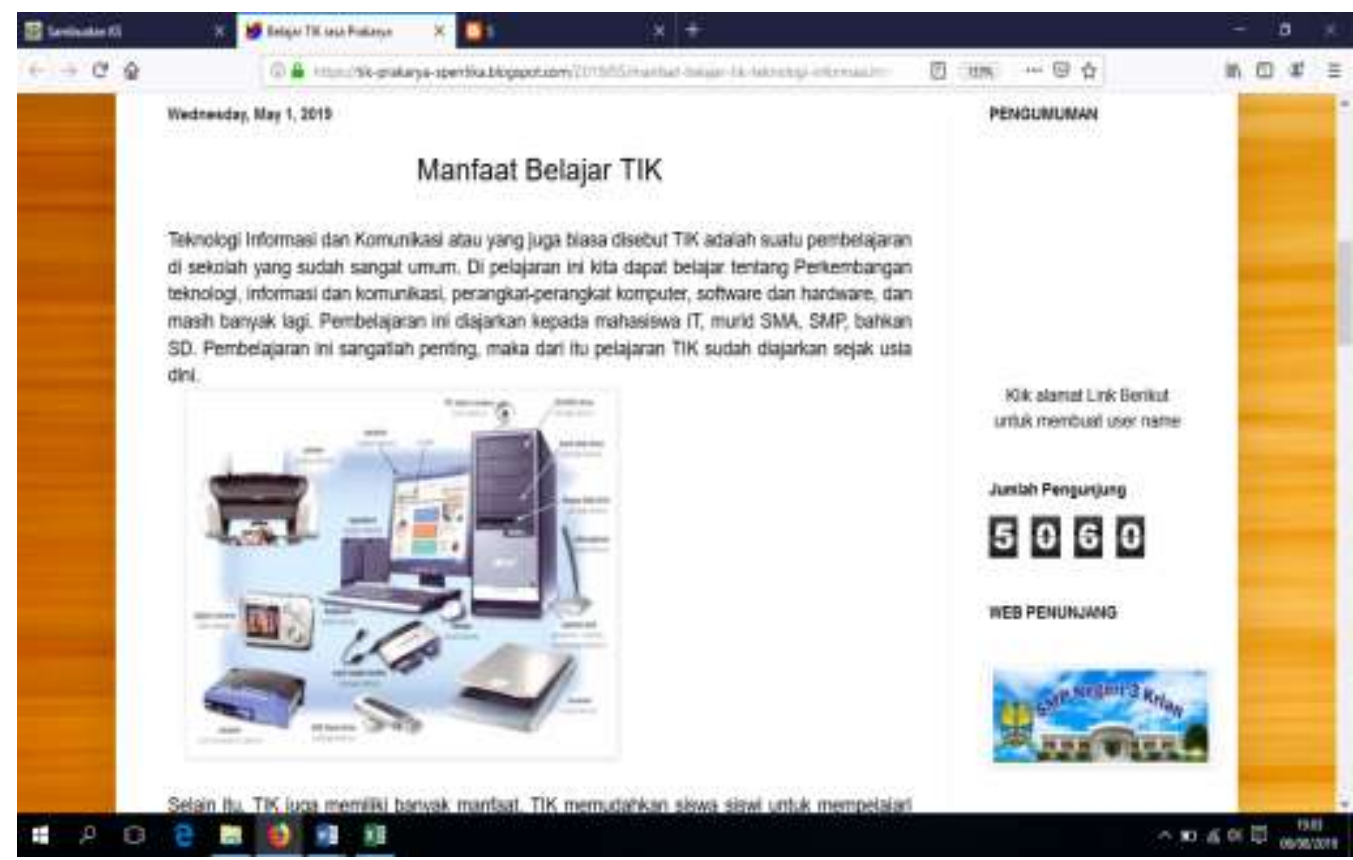

Gambar 8. Blog Pak Jusuf

Capaian dari kegiatan ini secara umum djelaskan sebagai berikut:

1) Dari 45 guru yang mengikuti pelatihan, maka ada 41 Blog yang sudah dapat diakses di laman website sekolah. Isi Blog yang didesain guru beragam namun ditentukan oleh karakteristik mata pelajaran masing-masing. Kelengkapan Blog juga beragam, masih jauh dari yang diharapkan dan perlu di per baharui di hari-hari mendatang.

2) J Kini pada website SMP Negeri 3 Krian telah dapat dimanfaatkan Blog Guru baik para siswa dan masyarakat umum.

Kegiatan ini cukup berhasi karena adanya jaringan internet yang memadai. Laboratorium Komputer juga dapat dimanfaatkan disamping Laptop yang dimiliki beberapa guru secara pribadi.

\section{KESIMPULAN}

\section{Simpulan}

Hasil dari kegiatan pengabdian masyarakat adalah tersedianya BLOG Guru SMP Negeri 3 Krian, Sidoarjo yang menjadi bahan ajar terbaharukan dari waktu ke waktu sehingga guru dapat menyediakan bahan ajar untuk pembelajaran yang sesuai dengan kebutuhan pembelajaran abad 21 ini.

\section{Saran}

Fasilitas yang dimilik oleh Sekolah SMPN 3 Krian, Sidoarjo, sangat mendukung untuk pembelajaran online learning. Selanjutnya perlu dilakukan rancangan pembelajaran secara terpadu dan diinterintegrasi dalam proses pembelajaran. 


\section{Tindaklanjut Pengabdian}

Kegiatan masih awal dan untuk keberhasilan perlu kegiatan lanjutan berupa pelatihan cara mendesain Blog terintegrasi dalam proses pembelajaran.

\section{UCAPAN TERIMAKASIH}

Ucapan terima kasih disampaikan kepada Lembaga Penelitian dan Pengambdian kepada Masyarakat Universitas PGRI Adi Buana dan SMPN 3 Krian, Sidoarjo, Jawa Timur yang telah berkolaborasi mendukung fasilitas dan pendanaan kegiatan ini.

\section{DAFTAR PUSTAKA}

Carr, Jenni. (2018). Eploring the implication of era big data' for learning and teaching. Availabel from URL: https://www.heacademy.ac.uk/explori ng-implications-\%E2\%80\%98-erabigdata\%E2\%80\%99-learning-and teaching

Cope, B. \& Kalantzis, M. (2016). Big Data Comes to School: Implications for Learning, Assessment, and Research. AERA Open April-June 2016, Vol. 2, No. 2, pp. $1-19$ DOI: 10.1177/2332858416641907. URL: http://ero.sagepub.com

David L. Problem Based Learning. (2014). Available from URL: https://www.learningtheories.com/problem-based-learningpbl.html

Degeng, I N. S, dan Degeng, P. D.D. (2017). Ilmu Pembelajaran: Klasifikasi Variabel untuk Pengembangan Teori dan Penelitian. Bandung: Yayasan Taman Pustaka Kristen Indonesia.

Hanipah, S., Florentius T.S, dan Rifai RC., A. (2018). The Effectiveness of Problem Based Learning and Project Based Learning Model to Improve Natural Science Study Outcomes. Innovation Journal of Curriculum and Educational Technology Vol.7 (1), p 1-6. Available from: URL: https://journal.unnes.ac.id/sju/index.php/ujet/article/view/24383

Konsep dan Implentasi Kurikulum 2013: Paparan Wakil Menteri Pendidikan dan Kebudayaan R.I Bidang Pendidikan, 14 Januari 2014. [118 screeens]. (2014). Availabel from: URL: https://www.kemdikbud.go.id/kemdikbud/dokumen/Paparan/Paparan\%20W amendik.pdf

Lai, E. R., Yarbro, J., DiCerbo, K., de Geest, E. (2018). Skills for Today: What We Know about Teaching and Assessing Creativity. London: Pearson Published. 5.

Maslim, M., \& Adithama, S.P.,. (2019). Pembangunan Sistem Informasi Perpustkaan Sekolah Dasar Berbasis WEB. Dinamisia: Jurnal Pengabdian Kepada Masyarakat, 3 (2), 350-360. URL: https://doi.org/10.31849/dinamisia.v3i2.3073

Núñez-del-Prado, Miguel \& Goméz, Rosario. (2017). Learning data analytics through a Problem Based Learning course. Proceedings 2017 IEEE World Engineering Education Conference (EDUNINE). Availabel from URL: https://ieeexplore.ieee.org/document/7918180/authors\#authors

Pusat Penelitian Ilmu Pengetahuan dan Teknologi (PUSPIPTEK RISTEKDIKTI). (2018). Sosialisasikan Teknologi, Puspiptek Rangkul Blogger. Available from: URL: http://puspiptek.ristekdikti.go.id/

Rahmah, E., Emidar, E., \& Zulfikarni, Z. (2018). Pengembangan Perpustakaan Sekolah Berbasis Teknologi Informasi di SMA Negeri 2 dan SMA Negeri 3 Padang. Dinamisia: Jurnal Pengabdian Kepada Masyarakat, 2(1), 6-13. https://doi.org/10.31849/dinamisia.v2i1.788

Setianingsih, W. , Rosana D., dan Setyawarno, D. (2018). Workshop Pemanfaatan Aplikasi Berbasis Komputer "CMI-SIPSMA Sistem Informasi Penilaian Sekolah" Bagi Guru Ipa Tingkat Smp Di Sleman, Yogyakarta. Jurnal Pengabdian Masyarakat MIPA dan Pedidikan MIPA, Vol 2, No.2 (2018), PP. Pp. 78-82. DOI: https://doi.org/10.21831/jpmmp.v2i2.21912

Sitompul, N.C., Rufi'i, Leksono, I.P., dan Rejeki, H. W. (2019). Meningkatkan Kompetensi Pendidik di Era Pembelajaran Abad 21 dengan Menjadi Guru Blogger. JPM (Jurnal Pemberdayaan 
Masyarakat Vol. 4 No. 1, pp: 330-338. Available from URL: http://ejournal.unikama.ac.id/index.php/jpm

SMP Negeri 3 Krian, Sidoarjo. (2019). Available from URL: https://www.smpn3krian.com

Southeast Asian Minister of Education Organization. Regional Online Learning Centre. (SEAMEOSEAMOLEC). Availabel from URL: https://seamolec.org/

World Economic Forum. (2018). The Future of Jobs Report 2018. Available from: URL: https://www.weforum.org/reports/thefuture-of-jobs-report-2018 